\title{
Centralisation of Power in the Pursuit of Law-based
} Governance

Legal Reform in China under the Xi Administration

Anthony H. F. Li

\section{OpenEdition}

\section{Journals}

Electronic version

URL: http://journals.openedition.org/chinaperspectives/6995

DOI: $10.4000 /$ chinaperspectives. 6995

ISSN: 1996-4617

\section{Publisher}

Centre d'étude français sur la Chine contemporaine

Printed version

Date of publication: 1 June 2016

Number of pages: 63-68

ISSN: 2070-3449

\section{Electronic reference}

Anthony H. F. Li, «Centralisation of Power in the Pursuit of Law-based Governance », China

Perspectives [Online], 2016/2 | 2016, Online since 01 June 2016, connection on 15 September 2020.

URL : http://journals.openedition.org/chinaperspectives/6995

(C) All rights reserved 


\title{
Cefe News Analysis
}

\section{Centralisation of Power in the}

\section{Pursuit of Law-based Governance}

\author{
Legal Reform in China under the Xi Administration
}

\author{
ANTHONY H. F. LI
}

Lt egal reform has been a prominent point on the agenda since Xi Jinping took over the leadership of the Chinese Communist Party (CCP). ${ }^{(1)}$ At the Third Plenum of the Party's $18^{\text {th }}$ National Congress in 2013, Xi proposed comprehensively pursuing four strategic political goals under the slogan "Four Comprehensives" (sige quanmian 四個全面). Two of the political goals, namely, to "comprehensively strengthen discipline of the Party" (quanmian congyan zhidang 全面從嚴治黨) and to "comprehensively rule the country according to the law" (quanmian yifa zhiguo 全面依法治國), set the grounds for the latest round of legal reform.

The Central Leading Group for Deepening Overall Reform (Zhongyang quanmian shenhua gaige lingdao xiaozu 中央全面深化改革領導小組) was set up to carry out the "Four Comprehensives." Deepening judicial reform in the direction of building a just and efficient judiciary that the citizens can trust is regarded as an integral part of the plan to comprehensively rule the country according to the law. (2) In fact, 13 out of the 19 plenary sessions of the Leading Group involved the topic of judicial reform from 2014 to 2015. (3)

The call for "ruling the country according to the law" can be dated back to September 1997, when Jiang Zemin at the $15^{\text {th }}$ CCP's National Congress addressed the need to construct the socialist state in accordance with the law (jianshe shehuizhuyi fazhi guojia 建設社會主義法治國家). ${ }^{(4)}$ In recent years, the Chinese term fazhi 法治 has re-emerged frequently in public discourse. Yet, observers of Chinese politics realise that the concept of fazhi by the Xi administration might not be best captured by the notion of "rule of law," but would be better interpreted as "rule by law." This article is intended to chart the details and implications of legal reform in the broader context of the pursuit of law-based governance and discusses the notion of fazhi under Xi's leadership.

\section{A legal system dominated by the CCP}

The Chinese legal institution is comprised of the Supreme People's Court (SPC), the Supreme People's Procuratorate (SPP), and the Ministry of Public Security, together with their relevant local agencies. Constitutionally, the $\mathrm{Na}-$ tional People's Congress (NPC) exerts oversight over the SPC and SPP, but such oversight is more nominal than substantial. A distinctive feature of China's legal system is the presence of the Central Political and Legal Affairs Commission of the CCP and its local Political and Legal Affairs Committees (PLAC) to ensure the Party's dominance over the legal system. The PLAC is vested with extensive power to oversee the courts and other legal institutions at both the ideological and organisational levels. ${ }^{(5)}$ It has a record of occasionally interfering in criminal cases, ${ }^{(6)}$ and of allowing the bureau of public security to overshadow the procuracy and the court in the legal process. ${ }^{(7)}$ The extent of the PLAC's power raises concerns about the vulnerability of judicial decisions to undue external influence as well as the risk of convicting innocent persons given the urge for local officials to close cases in order to achieve political targets. ${ }^{(8)}$ Observers point out that judicial corruption and wrongful convictions were particularly commonplace during the tenure of Zhou Yongkang as Vice-secretary and Secretary of the Central PLAC (2002-2012). ${ }^{(9)}$

The presence of the PLAC entails the question of the ambiguous relationship between the CCP and state laws. As Prof. Fu Hualing argues, the foundation of the constitutional order in China is the rule of the Party. This political reality places the Party Constitution over the state Constitution, although CCP cadres are supposed to act in accordance with the legal framework they have created. ${ }^{(10)}$ In this sense, the CCP politically

The author would like to express thanks to Séverine Arsène and Eric Florence for their valuable comments on the earlier draft of this article. All errors in this paper remain the responsibility of the author.

1. Carl Minzner, "Legal Reform in the Xi Jinping Era," Asia Policy, No. 20, July 2015, pp. 1-44.

2. Meng Jianzhu, "Shenhua sifa tizhi gaige" (Deepening judicial system reform), People's Daily, 25 November 2013, http://cpc.people.com.cn/n/2013/1125/c64094-23643019.html (accessed on 1 May 2016).

3. Supreme People's Court, White Paper on Judicial Reform of Chinese Courts, 3 March 2016, http://english.court.gov.cn/2016-03/03/content_23724636.htm (accessed on 5 April 2016).

4. Albert H.Y.Chen, "Toward a Legal Enlightenment: Discussions in Contemporary China on the Rule of Law," Pacific Basin Law Journal, Vol. 17, No. 2-3, 1999, p. 128.

5. Jacques Delisle, "China's Legal System," in William Joseph (ed.), Politics in China: An Introduction, $2^{\text {nd }}$ Edition, New York, Oxford University Press, p. 225.

6. Stanley B. Lubman, Bird in a Cage: Legal Reform in China after Mao, Stanford, Stanford University Press, 1999, p. 264.

7. Jerome A. Cohen, "A Looming Crisis for China's Legal System," Foreign Policy, 22 February 2016, http://foreignpolicy.com/2016/02/22/a-looming-crisis-for-chinas-legal-system (accessed on 14 April 2016).

8. Chen Guangzhong, "Bijiaofa shiye xia de Zhongguo tese sifa duli" (Principles of judicial independence with Chinese characteristics: A comparative law perspective), Journal of Comparative Law, No. 2, 2013, p. 8 .

9. See, for example, Cui Min, "Zhou Yongkang an de fansi yu jianyan" (Reflection and comments on the case of Zhou Yongkang), Yanhuang Chunqiu, No. 11, 2014, www.yhcqw.com/html/csl/2014/ 1111/141111145352EGB199661DI16CIK2H8KEI23.html (accessed on 25 April 2016).

10. Fu Hualing "China's Striking Anti-corruption Adventure: A Political Journey Towards the Rule of Law?", in Weitseng Chen (ed.), The Beijing Consensus? How China Has Changed the Western Ideas of Law and Economic Development, Cambridge, Cambridge University Press, 2016. 
transcends the legal system, and the responsibility for disciplining CCP cadres lies principally with the Party's Central Commission for Discipline Inspection (CCDI). Indeed, incriminated Party cadres are placed under investigation through an extra-legal procedure called "double designation" (shuanggui 雙規), where they are held in a "designated place" at a "designated time" until it is decided whether to expel them from the Party and/or hand them over to the courts. Prof. Yongshun Cai finds that only $8.7 \%$ of the 1,122 CCP members placed under such investigation were eventually sent to court, and most of them were low-ranking CCP members. ${ }^{(11)}$ From this perspective, the high-profile trials of a few former members of the CCP's Politburo Standing Committee, such as Bo Xilai and Zhou Yongkang, indicated the CCP's tacit consent to hand them over to the court.

Taking an instrumental approach to the legal institutions, the CCP has modified laws and legal institutions over the past decades to keep pace with its own need for economic reform, maintaining social stability, and sustaining the Party's rule. ${ }^{(12)}$ During the initial reform era, economic development was central to the development of legal institutions in tandem with the grooming of a more educated, professional, and capable judiciary to handle relevant ordinary cases. ${ }^{(13)}$ judges are also well aware of their assigned role to facilitate economic development up until recent times. (14)

Moreover, to alleviate social discontent and thus maintain social stability, the CCP has allowed citizens and enterprises to litigate in court against the wrongdoings of the government with administrative laws in place since 1989. (15) However, it is reported that courts tend to reject the registration of cases of this nature, ${ }^{(16)}$ and less than $10 \%$ of the verdicts ruled in favour of the plaintiffs before 2015. (17)

While legal reform was initially driven to bring the Chinese legal system in line with international standards, ${ }^{(18)}$ the bottom line of legal reform is the CCP's absolute leadership over legal institutions. China's leaders were afraid that a judiciary too powerful and independent of the Party's control would threaten the CCP's rule. Characterised by its limited autonomy, the Chinese judiciary has also long been criticised for its rampant corruption and unprofessionalism. Scholars also argue that the persistent insufficiency of financial resources has created a breeding ground for corruption, ${ }^{(19)}$ and that the practice of recruiting ex-servicemen from the People's Liberation Army into the judiciary has hampered the development of professionalism among judges. ${ }^{(20)}$

\section{The legal system under pressure in the $\mathrm{Hu}$ Jintao era}

Since the early 2000s, the continued development of legal institutions has been accompanied by a growing number of legal professionals such as judges and lawyers, especially after the introduction of the judicial examination system in 2001. The unintended consequence was the increased use of litigation to protect personal interests or individual rights guaranteed by the state Constitution. From the early 2000s onward, movements led by some rights defence (weiquan 維權) lawyers advocated the protection of citizens' rights within the constitutional constraints from the bottom up. (21) The weiquan movement was soon identified as a threat to social stability and repressed by the government.

At the same time, the socio-economic situation in China has become more complex than before with the fast-growing economy. The number of collective incidents by protestors across the country has increased sharply.
Prof. Sun Liping estimated that as many as 180,000 protests, riots, and other collective incidents took place in 2010 , four times more than the figure a decade ago. ${ }^{(22)}$ The judiciary soon found itself outmatched by societal demands for social dispute resolution. In order to maintain social stability (weiwen 維穩), the Hu administration encouraged diversified methods of dispute resolution, including non-litigation means such as mediation and administrative reconciliation by non-judicial state agencies to settle social disputes. (23) For example, "Letters and Visits" (xinfang 信訪) and the "Grand Mediation" (da tiaojie 大調解) were actively promoted as alternative ways of settling disputes. (24) Prof. Jacques Delisle argues that such practices have had a negative impact on the legal system, as the official preference for mediation over adjudication implies less concern for formal rights and clear rules. (25)

Moreover, local courts have been under heavy pressure to carry out stability maintenance, as judges are evaluated in significant part on this basis. (26) Such pressure has led them to deploy a variety of extra-judicial means to achieve political targets, such as shaming suspects or convicts in public despite the fact that the SPC has formally forbidden the use of public trials since the 1980s. ${ }^{(27)}$

The crisis of the judicial system has notably resulted in a talent drain that has been ongoing for ten consecutive years, as many qualified and experienced judges have quit their jobs. (28) Summarised by Prof. Xu Shenjian, the reasons include enormous pressure from heavy caseloads, poor salaries, limited opportunities for promotion, intervention by external agencies in the

11. Yongshun Cai, State and Agents in China: Disciplining Government Officials, Stanford, Stanford University Press, 2015, pp. 64, 75, and 95.

12. Jacques Delisle, "China's Legal System," art. cit.

13. Ibid., pp. 231-232.

14. Rachel E. Stern, "The Political Logic of China's New Environmental Courts," The China Journal, Vol. 72, July 2014, pp. 61-63.

15. Jacques Delisle, "China's Legal System," art. cit., p. 235.

16. Ian Johnson, "China Grants Courts Greater Autonomy on Limited Matters," The New York Times, 3 January 2016, http://cn.nytimes.com/china/20160103/03chinalaw/en-us (accessed on 23 March 2016).

17. Zhou Tian, "Zhongguo 'mingaoguan' shengsulü bu dao yi cheng" (Less than $10 \%$ success rate for citizens who sue government officials), Caixin, 5 November 2014, http://china.caixin.com/201411-05/100747143.html (accessed on 23 March 2016).

18. Benjamin L. Liebman, "A Return to Populist Legality?", in Sebastian Heilmann and Elizabeth J. Perry (eds), Mao's Invisible Hand: The Political Foundations of Adaptive Governance, Cambridge, MA, Harvard University Press, 2011.

19. He Xin, "Zhongguo fayuan caizheng buzu yu sifa fubai" (Financial deficiency of court and judicial corruption in China), Twenty-first Century Bimonthly, No. 105, February 2008.

20. He Weifang, "Fuzhuan junren jin fayuan" (Ex-servicemen recruited for the judiciary), Southern Weekly, 2 January 1998, www.21ccom.net/articles/zgyj/fzyj/2011/0518/35741.html (accessed on 1 May 2016).

21. Fu Hualing and Richard Cullen, "Weiquan (Rights Protection) Lawyering in an Authoritarian State: Building a Culture of Public-Interest Lawyering," The China Journal, No. 59, January 2008, pp. 111127.

22. Tom Orlik, "Unrest Grows as Economy Booms," The Wall Street Journal, 26 September 2011, www.wsj.com/articles/SB10001424053111903703604576587070600504108 (accessed on 1 May 2016).

23. Hu Jieren and Zhang Yang, "Breaking the Dilemma between Litigation and Non-litigation: 'Diversified Mechanisms of Dispute Resolution' in Contemporary China," China Perspectives, No. 2016/2, Pp. 47-55.

24. Benjamin L. Liebman, "A Return to Populist Legality?", art. cit.

25. Jacques Delisle, "China's Legal System," art. cit., p. 241.

26. Benjamin L. Liebman, "A Return to Populist Legality?", art. cit.

27. "Congpan daihui weihe lujinbuzhi" (Why "public trials" cannot be stopped), Caixin, 18 March 2016, http://opinion.caixin.com/2016-03-18/100921727.html (accessed on 17 April 2016).

28. "Zuigaofayuan gongzuo baogao lianxu shinian ti rencai liushi" (SPCWork Report mentions talent drain in ten consecutive years), Caixin, 13 March 2016, http://topics.caixin.com/2016-0313/100919588.html (accessed on 16 April 2016). 
Table 1 - Important documents related to law-based governance and judicial reform under the Xi Administration

\begin{tabular}{|c|c|c|}
\hline Name of document & $\begin{array}{l}\text { Issue } \\
\text { date }\end{array}$ & Remarks and significance \\
\hline $\begin{array}{l}\text { White Paper on Judicial Reform in China } \\
\text { (Zhongguo de sifa gaige baipishu 中國的司法改革白皮書) }\end{array}$ & $\begin{array}{l}\text { October } \\
2012\end{array}$ & $\begin{array}{l}\text { The first white paper on judicial reform in the PRC's history, issued by } \\
\text { the State Council }\end{array}$ \\
\hline \multicolumn{3}{|l|}{ Third Plenum of the $18^{\text {th }}$ Party Congress (9-12 November 2013) } \\
\hline $\begin{array}{l}\text { Decision of the Central Committee of the CCP on Some Major Issues } \\
\text { Concerning Comprehensively Deepening Reform } \\
\text { (Zhonggong zhongyang guanyu quanmian shenhua gaige } \\
\text { ruogan zhongda wenti de jueding } \\
\text { 中共中央關於全面深化改革若干重大問題的決定) }\end{array}$ & $\begin{array}{l}\text { November } \\
2013\end{array}$ & $\begin{array}{l}\text { The decision that spelled out the details of } \\
\text { the "Four Comprehensives" after the Third Plenum }\end{array}$ \\
\hline $\begin{array}{l}\text { Framework Opinions on Several Issues Concerning Judicial } \\
\text { System Reform } \\
\text { (Guanyu sifa tizhi gaige shidian ruogan wenti de kuangjia yijian } \\
\text { 關於司法體制改革試點若干問題的框架意見) }\end{array}$ & $\begin{array}{l}\text { June } \\
2014\end{array}$ & $\begin{array}{l}\text { The pilot project of judicial reform formally approved } \\
\text { by the Central Leading Group for Deepening Overall Reform }\end{array}$ \\
\hline $\begin{array}{l}\text { The Fourth Five-year Reform Plan of the People's Court (2014-2018) } \\
\text { (Renminfayuan disi ge wunian gaige gangyao } \\
\text { 人民法院第四個五年改革綱要 2014-2018) }\end{array}$ & $\begin{array}{c}\text { July } \\
2014\end{array}$ & $\begin{array}{l}\text { The first version of the judicial reform plan } \\
\text { by the Supreme People's Court }\end{array}$ \\
\hline \multicolumn{3}{|l|}{ Fourth Plenum of the $18^{\text {th }}$ Party Congress (20-23 October 2014) } \\
\hline $\begin{array}{l}\text { Decision of the Central Committee of the CCP on Major Issues } \\
\text { Pertaining to Comprehensively Promoting the Rule of Law } \\
\text { (Zhonggong zhongyang guanyu quanmian tuijin yifazhiguo ruogan } \\
\text { zhongda wenti de jueding 中共中央關於全面推進依法治國若干重大問題 } \\
\text { 的決定) }\end{array}$ & $\begin{array}{c}\text { October } \\
2014\end{array}$ & $\begin{array}{l}\text { The decision that set the promotion of law-based governance } \\
\text { of the country as top priority }\end{array}$ \\
\hline $\begin{array}{l}\text { Opinion Regarding Comprehensively Deepening Reform } \\
\text { of the People's Court } \\
\text { (Guanyu quanmian shenhua renminfayuan gaige de yijian } \\
\text { 關於全面深化人民法院改革的意見) }\end{array}$ & $\begin{array}{l}\text { February } \\
2015\end{array}$ & $\begin{array}{l}\text { A revised version of the Fourth Five-year Reform Plan of the People's } \\
\text { Court issued by the Supreme People's Court after the Fourth Plenum }\end{array}$ \\
\hline \multicolumn{3}{|l|}{ Fifth Plenum of the $18^{\text {th }}$ Party Congress (26-29 October 2015) } \\
\hline $\begin{array}{l}\text { Guidelines to Promote Law-based Governance (2015-2020) } \\
\text { (Fazhi zhengfu jianshe shishi gangyao 法治政府建設實施綱要 } \\
\text { 2015-2020) }\end{array}$ & $\begin{array}{l}\text { December } \\
2015\end{array}$ & $\begin{array}{l}\text { An outline of a plan for law-based governance jointly published by the } \\
\text { State Council and the Central Committee of the CCP for the first time }\end{array}$ \\
\hline $\begin{array}{l}\text { White Paper on Judicial Reform of Chinese Courts } \\
\text { (Zhongguo fayuan de sifa gaige baipishu } \\
\text { 中國法院的司法改革白皮書) }\end{array}$ & $\begin{array}{l}\text { February } \\
2016\end{array}$ & $\begin{array}{l}\text { A comprehensive summary of judicial reform since the } 18^{\text {th }} \text { Party } \\
\text { Congress issued by the Supreme People's Court before the two } \\
\text { sessions of the NPC and NPPCC in March } 2016\end{array}$ \\
\hline
\end{tabular}

Sources: China Daily, Legal Daily (Fazhi ribao), website of the Supreme People's Court, and Xinhua.

adjudication process, etc. ${ }^{(29)}$ Yet, it should be noted that the trend of officials leaving state positions for an alternative career in the economic market is not unique to the profession of judges, given the increasing pluralisation of jobs and greater material rewards offered by the fast-growing economy. ${ }^{(30)}$

\section{Legal reform as high priority under Xi Jinping's leadership}

Soon after Xi Jinping took over the CCP's leadership, the CCP took action to strengthen Party discipline with a large-scale anti-graft campaign, which created a favourable environment for reform of the judiciary. ${ }^{(31)}$ The CCP also promoted the agenda of law-based governance and deepened the extent of judicial reform at both the Third and Fourth Plenums of the $18^{\text {th }}$
Party Congress (see Table 1). Legal reform was gradually rolled out in three phases of pilot projects from June 2014 to January 2016.

Meanwhile, the Xi Administration has shown less tolerance for weiquan lawyers and bottom-up pressure than that of his predecessors. In July 2015, weiquan lawyers across the country faced an unprecedented, systematic crackdown, ${ }^{(32)}$ followed by many arrests for "picking quarrels

29. "Faguan cizhi weihe hui bei 'kan renao'" (Why people are interested in judge resignation), Caixin, 25 February 2016, http://opinion.caixin.com/2016-02-25/100912427.html (accessed on 16 April 2016).

30. Nanfeng chuang Bi-weekly, Vol. 25, 2-15 December 2015.

31. Samson Yuen, "Disciplining the Party:Xi Jinping's Anti-Corruption Campaign and its Limits," China Perspectives, No. 2014/3, pp. 41-47.

32. Samson Yuen, "Friend or Foe? The Diminishing Space of China's Civil Society," China Perspectives, No. 2015/3, pp. 51-56. 
and provoking trouble" and "subversion of state power" in the subsequent months. The latest round of legal reform remains a principally top-down initiative. The essence of the legal reform, as Carl Minzner succinctly puts it, is focused on the centralisation of control over local courts and the professionalisation of the judiciary. ${ }^{(33)}$ The following sections will discuss the two reform directions and analyse the implications of legal reform.

\section{Centralisation of control over local courts to curb local protectionism}

One significant aspect of legal reform is the transfer of responsibility for the management of personnel, finance, and property of local courts from local to provincial governments. Also, Circuit Tribunals (xunhui fating 巡迴法庭) have been established as an extended part of the SPC to deal with court cases that crosscut more than one legal jurisdiction. Stanley Lubman points out that these reforms are targeted at curbing the problem of local protectionism. (34) Until now, while the SPC and SPP have played a supervisory role over local courts and local procurators respectively, it has been the local government and local Party committee that has actually controlled the financial and personnel matters of judges and procurators at the local level. This administrative structure provides the institutional basis for local protectionism and subjects the local court and procuracy to the political interests of the local government. (35)

In order to keep local protectionism at the doorsteps of the judiciary, two other reform measures have also been introduced. First, the Case Registration System (li'an dengji zhi 立案登記制) has been in place since May 2015 to allow courts to accept all reported cases with minimal paperwork, unlike the previous Case Review System (li'an shencha zhi 立案審查制), where courts could reject any case due to heavy caseload or to avoid difficult cases. ${ }^{(36)}$ While the SPC in March 2016 claimed the Case Registration System a success, with $95 \%$ of cases registered successfully, some doubts over the accuracy of the figures based on other observations have also been expressed. (37)

Second, the SPC issued two regulations that force judicial officials to compile a database intended to report any persons, either within or outside the judiciary, who attempt to exert undue influence over the judicial process. ${ }^{(38)}$ Nonetheless, the effectiveness of this measure might be adversely affected by the intricate guanxi system, in which networks of personal connections utilised for personal benefit have long been entrenched in the judicial system. ${ }^{(39)}$ Those who have an interest in exerting influence over court cases are usually relatives, schoolmates, friends, or even superiors of the court officials who compile the record database.

In short, legal reform aims to leverage the authority of the central government to distance local courts from undue local influence, and thus to create a greater degree of autonomy for the judiciary to carry out its role of social dispute resolution as well as stability maintenance. ${ }^{(40)}$ Yet, given that provincial governments might not have sufficient tools to monitor local governments, it remains to be seen whether the top-down deterrence to the negative influence from both external and internal intervention into the judiciary can be as effective as stated in the above-mentioned legal reforms. Also, the reform only entails a shift of control from local to provincial governments, and the autonomy of the judiciary remains confined by the parameters set by the central government.

\section{Professionalisation of the judiciary}

In tandem with the reform to spearhead a greater degree of autonomy for the judiciary from local powers, two reform measures under Xi's leadership are intended to enhance the professionalism of the judiciary. First, the internal re-allocation of personnel roles within the courts (faguan yuan e zhi 法 官員額制) has been introduced to set the quota of judges in a reasonable ratio to other ancillary personnel so as to professionalise the role of judges and ensure that they are deployed to adjudicate cases and not to an unreasonable amount of administrative work. The judges so recognised after the personnel restructuring will receive better salary packages as well. Second, the experimental Judicial Responsibility System (sifa zeren zhi 司法責任制) allows judges who handle cases in trial to make verdicts and be held responsible for them for their entire careers and beyond. In contrast, the adjudication process now in place appears to be very bureaucratic. Judges examine cases in trial, but the final verdict is decided by their administrative superiors, the Adjudication Committee of each court. ${ }^{(41)}$ The reform with an aim of "de-administration" (qu xingzheng hua 去行政化) of the court not only enhances the personal prestige of frontline judges, but also increases the level of professionalism of the judiciary by barring high-ranking officials from internally intervening in cases. Prof. Susan Finder points out that this reform is oriented towards a "hearing-centred procedural system" that gives rise to a professional judiciary to deal with technical legal matters. ${ }^{(42)}$

The reform may nevertheless be hampered by a recent intensification of the exodus of many qualified judges from the judicial system. Zhu Shaoming argues that the introduction of the reform on the re-allocation of the judge's role has contributed to this phenomenon because the number of legal staff holding the title of judges will be reduced significantly, and consequently the number of cases handled by each judge will be sharply increased. ${ }^{(43)}$ In fact, the nationwide number of newly registered cases handled by local courts increased sharply from 954,000 in 2013 to 19,511,000 in 2015. (44) Prof. Jerome A. Cohen also observed that many judges who quit are young because their career prospects are severely limited by the current reform that favours older, often less-qualified colleagues. ${ }^{(45)}$

33. Carl Minzner, "Legal Reform in the Xi Jinping Era," art. cit.

34. Stanley Lubman, "China's Highest Court Eyes Judicial Reform, While a Lawyer Criticizes TV Confessions," The New York Times, 11 March 2016, http://blogs.wsj.com/chinarealtime/2016/03/11/ chinas-highest-court-eyes-judicial-reform-while-a-lawyer-criticizes-tv-confessions (accessed on 12 April 2016)

35. He Xin, "Zhongguo fayuan caizheng buzu yu sifa fubai," art. cit.

36. Gao Changjian, "Li'an dengji zhi pojie 'li'an nan"' (Case Registration System solves the problem with the previous hardship in registering cases), Study Times, 4 May 2015, http://theory.people.com.cn/n/2015/0504/c40531-26943431.html (accessed on 24 April 2016)

37. Radio Free Asia, "Zhonguo zuigao fa cheng sifa gaige qude chengguo lüshi gongmin qi zhiyi" (SPC claims success in judicial reform, lawyers and citizens doubt it), 1 March 2016, www.rfa.org/mandarin/yataibaodao/renquanfazhi/yf1-03012016105415.html (accessed on 16 April 2016).

38. "Jinnian bixu wancheng sifa gaige zhuti kuangjia goujian" (The construction of the major framework of judicial reform must be completed this year), Sina Finance, 7 March 2016, http://finance .sina.com.cn/roll/2016-03-07/doc-ifxqaffy3723979.shtml (accessed on 24 April 2016).

39. Jerome A. Cohen, "China's Legal Reform at the Crossroads," art. cit.

40. Susan Finder, "China's Master Plan for Remaking its Courts," The Diplomat, 26 March 2015, http://thediplomat.com/2015/03/chinas-master-plan-for-remaking-its-courts (accessed on 16 April 2016).

41. Jerome A. Cohen, "China's Legal Reform at the Crossroads," art. cit.

42. Susan Finder, "China's Master Plan for Remaking its Courts," art. cit.

43. Zhu Shaoming, "Comments on 'A Looming Crisis for China's Legal System,', Law at the End of the Day blog, 27 February 2016, http://lcbackerblog.blogspot.hk/2016/02/shaoming-zhou-on-jeromecohen-looming.html (accessed on 16 April 2016).

44. The Supreme People's Court Annual Work Reports 2013-2015, published by Xinhua.

45. Jerome A. Cohen, "A Looming Crisis for China's Legal System," art. cit. 


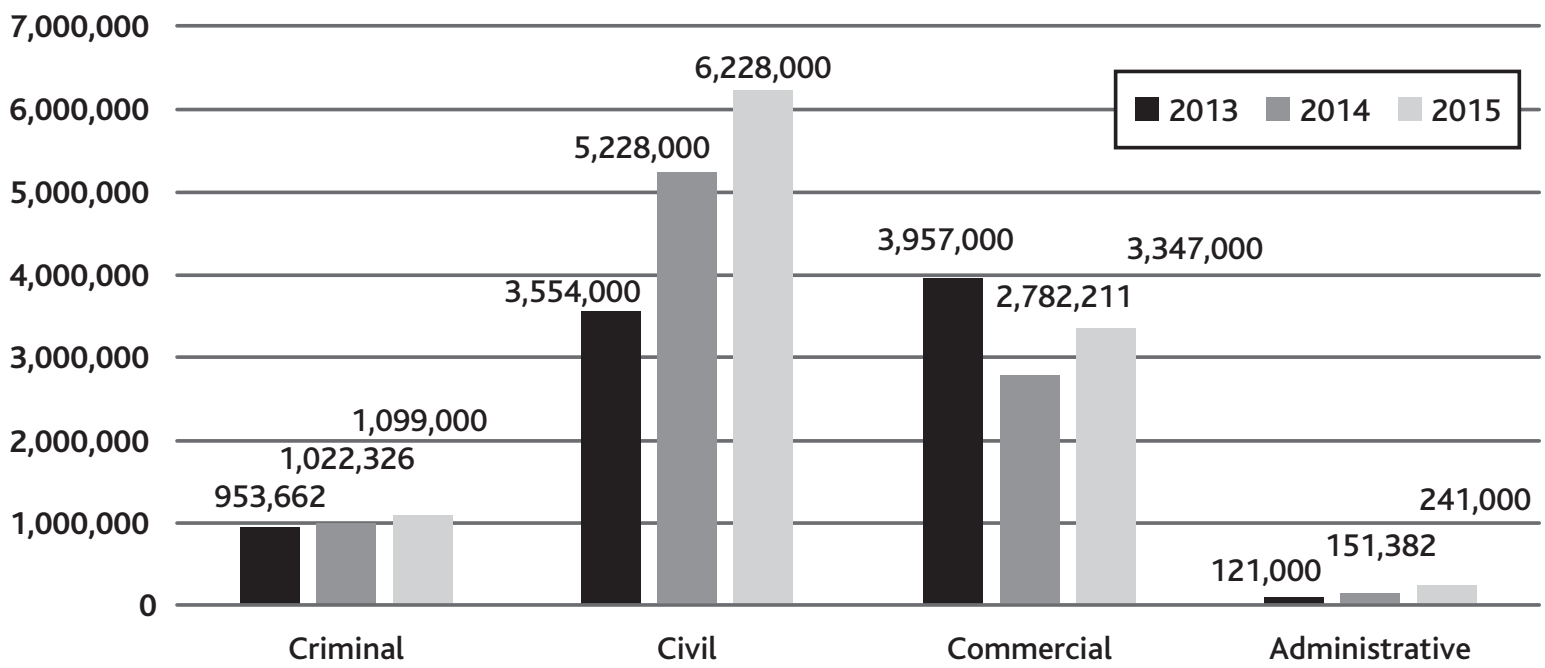

Source: Supreme People's Court Annual Work Reports published by Xinhua, 2013-2015.

\section{Redefining the Party's control at arm's length}

The relationship between the CCP and the judiciary is also redefined. Notwithstanding the continued leadership of the CCP, the PLAC's control over the judiciary is to be withdrawn and exercised at arm's length with an aim to expanding the degree of autonomy of the judiciary and to enhance judicial professionalism. The fact that the head of the Central PLAC is no longer a member of the Standing Committee of the Politburo (after the fall of Zhou Yongkang) could make the retraction of the PLAC's power easier to achieve.

According to the reform, local party cadres will be deprived of the authority to nominate local judges and procurators for appointment or removal. A new Selection Committee led by provincial-level Party cadres and including non-Party members will nominate a list of eligible candidates. The subprovincial People's Congress controlled by the sub-provincial party committee, however, will continue to hold the power to appoint or remove judges according to the state Constitution, but only by picking from the list established by the Selection Committee. ${ }^{(46)}$

The functions of the PLAC are also re-defined. In August 2013, Meng Jianzhu 孟建柱, the Secretary of the Central PLAC, urged local PLACs to refrain from intervening in individual cases. ${ }^{(47)}$ In addition, since July 2015, all heads of provincial-level PLACs no longer hold the position of heads of provincial-level public security bureaus, ${ }^{(48)}$ although the two positions remain held by the same person at the central level. This arrangement is to a certain extent helpful in preventing the overshadowing of the judiciary by the public security bureau. The focus of the PLAC has now been redirected toward mediating social conflicts and coordinating the interests of various agencies in the legal system, with stability maintenance as the overarching objective. ${ }^{(49)}$

\section{Conclusion: The nature of law-based governance}

The latest round of legal reforms is substantial, as the Xi Administration is attempting to tackle the problems of local protectionism and limited profes- sionalism of the judiciary by centralising control over local courts as well as streamlining the professional management of the judiciary. Also, the CCP redefined the role of the PLAC and reduced its scope of operations. Yet, in the pursuit of law-based governance for China, the emphasis remains on the Party's leadership, as Prof. Hu Jianmiao points out. ${ }^{(50)}$

From the perspective of the CCP, the success of legal reform might contribute to the longevity of its rule. First, a professionalised judiciary might facilitate sustainable economic development in the long run by creating a business-confident environment and settling commercial disputes efficiently, especially in China's most developed areas, where economic transactions between strangers have been increasing and people rely less on guanxi to seal business deals. (51)

Second, while the CCP is not completely forgoing the utility of the nonlitigation mechanism strongly promoted by the Hu Administration, the new generation of China's leaders wants to bring the judiciary back to the centre of social dispute resolution and restore public confidence in its capacity to deliver fairness and justice, so that it can help relieve pressure for stability maintenance, especially given the huge demand indicated by the sharp increase in civil case registrations with the courts (see Graph 1).

Third, the process of judicial centralisation and professionalisation is conducive to the enhancement of the central government's capacity to monitor local governments for their failure in public good provision as exemplified

46. Jiang Wei and Yang Jinzhi, "Shanghai sifa gaige shidian" (The pilot judicial reform in Shanghai), Xinhua, 14 July 2014, www.acla.org.cn/html/xinwen/20140714/17307.html (accessed on 27 April 2016).

47. Xing Bingyin, "Zhongyang zhengfawei zhineng zhuanxing" (Changing the role of the Central Political Legal Affairs Commission), The Paper, 21 January 2016, www.thepaper.cn/newsDetail_forward_1423017 (accessed on 16 April 2016)

48. "31 shengji zhengfawei shuji jun buzai jianren gongantingzhang" (31 provincial-level PLAC heads no longer heads of public security bureau), The Beijing News, 24 June 2015, www.bjnews.com.cn/news/2015/06/24/368177.html (accessed on 5 May 2016).

49. Jean Mittelstaedt, "A Reply to Jerome A. Cohen," Law at the End of the Day blog, 27 February 2016, http://lcbackerblog.blogspot.hk/2016/02/jean-mittelstaedt-on-jerome-cohen.html (accessed on 16 April 2016)

50. "Zhuanjia jiedu 'fazhi zhengfu jianshe shishi gangyao"' (Experts interpret the Guideline to promote law-based governance), Legal Daily, 10 January 2016, www.legaldaily.com.cn/index/content/ 2016-01/10/content_6438940.htm?node=20908 (accessed 16 April 2016).

51. Jacques Delisle, "China's Legal System," art. cit., p. 231. 
by the introduction of public interest litigation availed by the new Environment Protection Law since 2015. Although the de-centralisation of the Chinese political structure has been instrumental in high-speed economic growth in the past decades, the resulting negative environmental and social consequences have raised concerns in the central government as increasing public discontent towards those consequences could undermine the political legitimacy of the central authorities. In light of this, the centralisation of the judiciary is not just a means of strengthening judicial power, but also an end for the central government to monitor recalcitrant local governments that refuse to remedy the situation. Developing the state's capacity to rule the country according to the law and centralising political power seem to be two sides of the same coin in terms of the law-based governance proposed by the Xi Administration.

The very fact that centralisation of political power is the nature of the current top-down legal reform implies that the crafted autonomy from local protectionism and enhanced professionalism of the judiciary can easily suffer from the vertical intervention of the central government when deemed necessary. For example, in the shadow of the economic slowdown, the judiciary has been subject to national pressure to revive the momentum of economic growth with the PLAC in place. After all, the development of judicial autonomy and professionalism is at best secondary to the agenda of the Party's sustainable rule.

Last but not least, the current legal reform sheds light on how China's leaders conceptualise the notion of fazhi. As Prof. Fu Hualing argues, the two-faceted emphasis on the rule-based regulation of the behaviour of party cadres and the law-based control of the behaviour of government officials, despite being rhetorical at times, signifies the top leaders' com- mitment to the pursuit of a law-based country, which might represent a tiny step towards "rule of law." (52) This argument is appealing if we look at the situation under the $\mathrm{Hu}$ administration. Nevertheless, the requirement for rule/law-abiding behaviour seems to apply only to the levels below the central authority. With the continued control of the Party over the state machinery, and the transcendent position of Politburo members in the Party, the current legal reform shows that the view of Politburo members towards fazhi may be better characterised by the notion of "rule by law," where the enforcement of law is subject to the top leaders and they can turn a blind eye to law-breaking behaviour if such a response is deemed politically desirable. For example, the legal principle of "presumption of innocence" has been frequently compromised in recent times with the increasing use of televised confessions by state-owned media to denounce suspects who have not yet entered the legal process. ${ }^{(53)}$ In this light, whether legal reform can really achieve the goal of delivering fairness and justice to every citizen is subject to three conditions: the extent to which the reforms can curb local protectionism, the level of professionalisation of the judiciary, and the commitment to such goals by the central government.

\section{Inthony H. F. Li is a research assistant at CEFC (anthonylihf@gmail.com).}

CEFC News Analysis is compiled from the CEFC's fortnightly selection of Press Highlights, available at www.cefc.com.hk.
52. Fu Hualing, "China's Striking Anti-corruption Adventure," art. cit.

53. Zhao Sile, "Guanmei shenpan, zhe sun le shei?" (Trial by state-owned media, who is hurt?), The Initium, 3 April 2016, https://theinitium.com/article/20160403-opinion-zhaosile-media (accessed on 16 April 2016). 